\title{
Da Lili Elbe fik en ny identitet
}

Af Bente Rosenbeck

OG YVONNE MørCK

var vi på tur til Dresden og benyttede lejligheden til at besøge Lili Elbes gravsted på Trinitatiskirkegården. Besøget bød på flere overraskelser. I april 2016 var der blevet sat en ny gravsten på hendes grav, rekonstrueret efter et historisk foto. Nedenunder et ornament i jugendstil står der ikke andet end Lili Elbe, født i Danmark, død i Dresden. Det stod også på den originale gravsten. ${ }^{1}$

Graven havde ligget hen siden 1960'erne, men var ikke blevet genbenyttet. Det var produktionsselskabet bag filmen Den danske pige, som havde finansieret gravstenen. Sachsens ligestillingsminister Katja Köpping fra SPD (det tyske socialdemokrati) holdt tale for de ca. 100 tilstedeværende, heriblandt en repræsentant for den danske ambassade, forfatteren David Ebershoff $^{2}$ og drejebogsforfatter Lucinda Coxon.

Det overraskende var, at Lili i denne tale var blevet til en interkønnet person. "Intersexuelle Lili Elbe wird Kinostar og erhält wieder Grabstein in Dresden" lød over- 
skriften i Dresdner Neueste Nachrichten. ${ }^{3}$ Det samme kunne vi læse i det lokale kirkeblad, som hang på opslagstavlen ved en af indgangene til kirkegården, og i Frankfurter Allgemeine Zeitung, hvor Elbe presenteres som interkønnet kunstner. ${ }^{4}$ Hvad var nu det? Har de transkønnedes urmoder skiftet identitet? Den tyske udgave af Wikipedia udråber hende også til at være et af de første 'interseksuelle mennesker', som gennemgik en kønskorrigerende operation, og skriver endvidere, at Lili blev født med såvel mandlige som kvindelige kønsorganer. Dansk Wikipedia nøjes med at slå fast, at Lili var den første mand i verden, der fik foretaget en "kønsskifteoperation". Hvad er rigtigt, og hvad er forkert?

Lidt research førte os forskellige steder hen. Niki Trauthwein har skrevet en lille biografi om Elbe publiceret på Bundesstiftung Magnus Hirschfelds hjemmeside, hvor hun omtales som en af de første, der gennemgik "geschlechtsangleichende Operationen". 5 Ikke et ord om interkøn. Niki Trauthwein er leder af Lili Elbe Archiv Forschungsstätte zur Inter, Trans und Queergeschichte e.v. Hvad med at opsøge dette arkiv? Det viste sig, at det lå lige i nærheden af, hvor vi boede - og på hjørnet af Elbe Strasse! Nok tilfældigt, for arkivet befinder sig i et privat hjem, men bliver sponsoreret af Magnus Hirschfeld-stiftelsen. ${ }^{6}$

Niki Trauthwein mente ikke, at der var noget om sagen, men måske udtryk for ønsketænkning fra de tyske interkønnede organisationer. Er der belæg for denne "identitetsændring"? Den er i hvert fald ikke grebet ud af den blå luft. Det er ved flere lejligheder blevet antydet, at Lili var hermafrodit, hvilket var den betegnelse for interkønnede, der blev brugt i hendes samtid. E.P. Dutton, som udgav den første engelske oversættelse af bogen: Man into Woman: An Authentic Record of a Change of Sex i 1933, præsenterede bogens hovedperson som "a form of hermaphrodite, with 'stunted and withered ovaries' as well as testicles".?

Det var heller ikke ualmindeligt at sam- menblande fænomener, der i dag bliver betegnet særskilt som transkønnethed og interkønnethed, på det tidspunkt. Lili blev omtalt som en pseudohermafrodit af sin læge Kurt Warnekros. Det fremgår af Sabine Meyers bog: "Wie Lili zu einem richtigen Mädchen wurde". Lili Elbe: Zur Konstruktion von Geschlecht und Identität zwichen Medialisierung, Regulierung und Subjektiverung, som udkom i 2015 (s. 271272, se også s. 197, 212, 263, 295; en boganmeldelse af Meyers bog findes i Thomsen 2016). Ifølge Meyer fandt Knud Sand, professor i retsmedicin på Københavns Universitet, dog ikke bevis for, at Einar Wegener var af kvindekøn i de lægeerklæringer, som Warnekros havde sendt. 'På grund af omstændighederne', herunder de foretagne operationer og ud fra antagelsen om, at "den paagældende repræsenterer et sexuelt Mellemstadium med stærk Tendens i kvindelig Retning" (Meyer 2015, 285), anbefalede Sand og resten af Retslægerådet dog et andragende til Justitsministeriet fra Wegener om at få opløst sit xgteskab og ændret sit juridiske køn. Også Magnus Hirschfeld, som nok var datidens største ekspert på transkønnethed, udelukkede en hermafroditdiagnose (ibid., 269, 295). Warnekros holdt til gengæld fast ved diagnosen "pseudohermafroditismus femininus" - muligvis af strategiske grunde, da det var mere legitimt at operere en interkønnet person end en transperson.

En hermafroditdiagnose kunne være en måde, hvorpå man kunne forsvare kirurgiske indgreb som værende nødvendige. Muligheden for, at det var den rigtige diagnose, kan næppe helt udelukkes, og de originale lægejournaler i Elbes sag brændte under bombardementet af Dresden i 1945. Samtidig har Warnekros haft sine motiver til at fastholde diagnosen, så vi kan næppe stole på ham. Sabine Meyer har fremlagt sagen, men tager i bogen ikke direkte stilling $\mathrm{i}$ forhold til Lili. Det gør til gengæld omtalen af Meyers bog på Amazon. Her bliver Lili udråbt til en perfekt hermafrodit: "Vermeintlich als 
Mann geboren und operativ transformiert, avanciert Elbe 1931 zum Sinnbild moderner Medizin: perfekter Hermaphrodit und erste technologisch geschaffene Frau zugleich". ${ }^{8}$ Måske stammer Lilis nye identitet i Dresden derfra, måske fra den tyske udgave af Wikipedia, men hvilke beviser har Wikipedia? Beviset for, at Lili blev født med mandlige såvel som kvindelige organer, er hentet $\mathrm{i}$ bogen: Fra mand til kvinde. Hvad står der så her? Såvel historien om Lili Elvenes, som blev hendes rigtige navn, og romanen om Lili Elbe er kompliceret med et lag af forskellige fortællinger (Meyer 2011; se også Andreassen 1989). I bogen hedder Einar Andreas og Warnekros Werner Kreutz. I beskrivelsen af det første møde mellem Andreas og professor Kreutz udtaler professoren "tørt og sagligt", at:

“jeg antager nemlig, at De har kvindelige, saavel som mandlige Organer, men at ingen af dem har haft Mulighed for at udvikle sig helt ..... det er en Lykke for Dem, at De i en saa udpræget Grad føler Dem som Kvinde ...... derfor tror jeg, at jeg kan hjxlpe Dem" (Hoyer 1932, 17).9

Lili troede, at lægen også kunne hjælpe hende til at føde et barn og gøre hende yngre, men på det sidste punkt sagde Warnekros dog fra. Det fremgår af Sabine Meyers bog, hvor der findes en kopi af en side $\mathrm{i}$ manuskriptet til bogen, hvor Kurt Warnekros har overstreget løftet om foryngelse (Meyer 2015, 265). Bevisførelsen er således gået lidt i ring. Ingen tvivl om, at tysk Wikipedia ville dumpe til metodeeksamen i historie. Hverken denne lidt mærkelige og komplicerede bog af en livsberetning eller Warnekros' stædige fastholdelse af diagnosen "pseudohermafroditismus femininus" kan man tage helt for gode vare. Men historien cirkulerer, og også i Australien er Lili blevet til en interkønnet person. OII Organisation Intersex International Australien skriver f.eks. på en hjemmeside, at "Published autobiographies written by intersex pe- ople are rare", og så făr vi historien om Lili som et eksempel. 10

Både det med foryngelse og at kunne føde et barn var mere end tvivlsomt - også taget i betragtning, at Lili nærmede sig de 50 år, da hun blev opereret. Fotografier af hende viser en noget anden Lili, mere svarende til sin alder end på Gerda Wegeners malerier. Ifølge Lilis beretning har Warnekros udført mirakler. Professoren havde endog lovet hende at opfylde hendes største ønske, at føde et barn. Det anses i dag stadig for at være umuligt ifølge journalisten Susanne Kailitz, som bl.a. har interviewet en urolog og en medarbejder på Institut for Medicingeschichte i Dresden (Kailitz 2012). Mere sikkert er det, at Lili Elbe døde i september 1931 knap 1 1/2 år efter den første operation. Dødsårsagen blev i romanen angivet som opblusning af "en gammel nyresygdom" (Hoyer 1932, 183), mens Meyer har fundet indikationer for hjertestop som følge af en urinvejsinfektion, der udviklede sig efter den sidste af Lilis operationer og spredte sig til nyrerne via blodbanen (Meyer 2015, 281).

Vi møder i bogen nogle helt urealistiske forestillinger om udsigten til en succesfuld livmodertransplantation. Warnekros publicerede aldrig noget om sagen, men ud fra de historiske kilder er det højst usandsynligt, at han skulle have prøvet at udføre en sådan operation. Andre af hans efterladenskaber kan ses på det medicinhistoriske instituts udstilling Institut für Geschichte der Medizin i Dresden. ${ }^{11}$

Så vi kom ikke videre i sagen. Kommende forskning kan måske komme nærmere gåden, og det er vel også til at leve med, at Lili både er de transkønnedes og interkønnedes urmoder.

Vi fik endnu en overraskelse, da vi på vejen ud ville se Trinitatiskirken. Vi åbnede døren og steg ind i en ruin, der blev brugt til mange kunst arrangementer: kunst og teater. Bl.a. havde unge kunstnere lavet 'mosaik'-kirkevinduer af engangslightere i forskellige farver. Dresden, som var sønderbombet efter Anden Verdenskrig, er genop- 
bygget, men denne ruin minder om, hvordan byen så ud engang. Indtil videre kan Lili Elbes grav beses her; dog er den ikke helt let at finde.

\section{Noter}

1. http://www.gravsted.dk/person.php?navn=lilielbe. Bemærk at flere af de biografiske og historiske oplysninger i teksten, der ledsager fotoet, er faktuelt forkerte.

2. Filmatiseringen tager især udgangspunkt i David Ebershoffs bog Den danske pige, som udkom i 2000, og som ifølge bagsideteksten "bygger løseligt over det danske kunstnerægtepar Gerda og Einar Wegeners liv”. Der står også, at Einar Wegener som den første nogensinde fik foretaget en kønsskifteoperation, hvilket ikke er rigtigt.

3. Freitag 22.04.2016. t.dnn.de

4. http://www.faz.net/aktuell/gesellschaft/ menschen/intersexueller-kuenstler-ein-neuergrabstein-fuer-lili-elbe-in-dresden-14193799.html 5. http://mh-stiftung.de/biografien/lili-elbe/ 6. http://www.lili-elbe-archive.org/ 7. Meyerowitz $(2002,30)$ nævner eksempler på andre, som før Elbe gennemgik en kønsskifteoperation. Dette skete ofte i Berlin.

8. http://www.transcript-verlag.de/978-3-83763180-7/wie-lili-zu-einem-richtigen-maedchenwurde

9. Meyer $(2015,339)$ har en oversigt over de forskellige udgaver af Fra Mand til Kvinde. Udgiveren er Ernst Harthern, som gemmer sig bag pseudonymet Niels Hoyer (se Meyer 2015, 36).

10. https://oii.org.au/789/book-review-manwoman/

11. https://tu-dresden.de/med/mf/ges/das-institut/beschaeftigte

\section{LITTERATUR}

- Andreassen M. 1989. Boganmeldelse af Fra mand til Kvinde. Lili Elbes bekendelser, Skipperhoved 1988. Kvindeforskning, Nyhedsbrev nr. 2, 1989. - Hoyer, N. [Ernst Harthern] 1932. Fra mand til kvinde: Lili Elbes bekendelser. København: Hage \& Clausen.

- Kailitz. S. 2012. Das Experiment. Die Zeit. 3/2012. ZeitOnline.

- Meyer, S. 2011. Divine Interventions. (Re)birth and Creation Narratives in Fra Mand til KvindeLili Elbes Bekendelser. Kvinder, Kon \& Forskning. $20(3-4), 73-81$.

- Meyerowitz, J. 2002. How Sex Changed. A History of Transsexuality in the United states. Cambridge, Massachusetts: Harvard University Press.

- Thomsen, B.M.S. 2016. Skriftens krydsfelt i diskursen om transkønnethed. [Boganmeldelse af Meyer, S. 2015. "Wie Lili zu einem rightigen Mädchen wurde". Lili Elbe: Zur Konstruktion von Geschlecht und Identität zwishen Medialisierung, Regulierung und Subjektivierung. Bielefeld: transcript Verlag.] Kvinder, Køn \& Forskning. 25 (2-3), 108110. 